\section{Prestorage Low-oxygen Atmosphere Treatment Reduces Chilling Injury Symptoms in 'Fuerte' Avocado Fruit}

\author{
Edna Pesis, Rosa Marinansky, Giora Zauberman, and Yoram Fuchs \\ Department of Postharvest Science of Fresh Produce, Agricultural Research \\ Organization, The Volcani Center, P.O. Box 6, Bet Dagan 50250, Israel
}

Additional index words. sulfhydryl groups, respiration, ethylene production, electrolyte leakage, Persea americana

\begin{abstract}
Prestorage treatment of avocado fruit (Persea americana Mill. cv. Fuerte) with a low- $\mathrm{O}_{2}$ atmosphere $\left(3 \% \mathrm{O}_{2}+97 \% \mathrm{~N}_{2}\right)$ for 24 hours at $17 \mathrm{C}$, significantly reduced chilling injury (CI) symptoms after storage at $2 \mathrm{C}$ for 3 weeks. Fruit softening was also delayed by this treatment. The treated fruit had lower respiration and ethylene production rates during storage at $2 \mathrm{C}$ and subsequently at $17 \mathrm{C}$. Electrolyte leakage was significantly lower in peel disks from treated fruit. Reducing power, expressed as total sulfhydryl groups, was higher in the peel and pulp of low- $\mathrm{O}_{2}$-treated fruit. The amount of peel chlorophyll was inversely correlated with the severity of CI symptoms.
\end{abstract}

The avocado is a subtropical fruit sensitive to chilling injury $(\mathrm{CI})$ when exposed to low but nonfreezing temperatures. The main symptoms of CI are black spots on the peel and a gray or dark-brown discoloration of the mesocarp (Chaplin et al., 1982; Zauberman et al., 1985). 'Fuerte' avocados exhibited CI symptoms after only 10 days of storage at $2 \mathrm{C}$ (Zauberman et al., 1985). Lyons (1973) suggested that electrolyte leakage and disrupted ion balance resulting from ultrastructural changes in membranes lead to development of CI symptoms. Increased ion leakage is characteristic of many plant tissues that show CI symptoms (Hariyadi and Parkin, 1991; Lafuente et al., 1991; McCollum and McDonald, 1991).

Pretreatments with $\mathrm{N}_{2}$ at $\geq 97 \%\left(\right.$ low $\left.\mathrm{O}_{2}\right)$ atmospheres or with air enriched with $30 \%$ to $90 \% \mathrm{CO}_{2}$ delay ripening in various fruit and vegetables. Exposing preclimacteric bananas (Musa sp.) to $1 \% \mathrm{O}_{2}+99 \% \mathrm{~N}_{2}$ for 3 days, followed by storage in air, extended the time required for the fruit to ripen (Wills et al., 1982, 1990). Exposure to anaerobic conditions using either $\mathrm{CO}_{2}$ or $\mathrm{N}_{2}$ removed astringency of persimmon fruit by inducing the production of acetaldehyde (AA) and ethanol and led to retention of fruit firmness (Pesis and Ben-Arie, 1984). Treatments with high $\mathrm{N}_{2}$ or $\mathrm{CO}_{2}$ for 24 to $48 \mathrm{~h}$, which resulted in increased endogenous AA and ethanol, inhibited ripen-

Received for publication 12 July 1993. Accepted for publication 15 Mar. 1994. Supported by grant no. Is1787-90 from the U.S.-Israel Binational Agricultural Research and Development Fund (BARD). We express our appreciation to Joshua D. Klein for his critical review of the manuscript. Contribution from the Agricultural Research Organization, The Volcani Center, Bet Dagan, Israel. no. 1142-E, 1993 series. The cost of publishing this paper was defrayed in part by the payment of page charges. Under postal regulations, this paper therefore must be hereby marked advertisement solely to indicate this fact. ing in tomato (Lycopersicon esculentum Mill.) (Kelly and Saltveit, 1988; Pesis and Marinansky, 1993). In peaches and nectarines [Prunus persica (L.) Batsch], the insoluble pectin content remained higher and polygalacturonase activity showed a slower increase in fruit treated with $\mathrm{AA}, \mathrm{CO}_{2}$, or $\mathrm{N}_{2}$ (Lurie and Pesis, 1992).

Prestorage treatments of citrus fruit with $10 \%$ to $40 \% \mathrm{CO}_{2}$ in air reduced CI symptoms during cold storage (Bertolini et al., 1991; Hatton et al., 1975). Exposing 'Hass' avocado to $20 \% \mathrm{CO}_{2}$ three times during 21 days at $4 \mathrm{C}$ reduced CI (Marcellin and Chaves, 1983). Storing avocado in polyethylene bags also reduced CI symptoms (Scott and Chaplin, 1978). Treating 'Fuerte' avocado with $25 \%$ $\mathrm{CO}_{2}$ for 3 days before 28 days of storage at $5 \mathrm{C}$ reduced incidence of disorders and lowered the total phenols level (Bower et al., 1989).

Oxidative stress, an early response of cucumber (Cucumis sativus $\mathrm{L}$.) fruit to chilling at $4 \mathrm{C}$, caused a major reduction in glutathione and $\alpha$-tocopherol levels within 2 days of chilling (Hariyadi and Parkin, 1991). An association between enhanced cold hardiness of plants and increasing sulfhydryl (SH) content was demonstrated earlier (Levitt et al., 1962). Endogenous SH groups increase during fruit ripening, and a role of detoxificant agents was suggested for them (Fuchs et al., 1981; Tabachnik-Ma' ayan and Fuchs, 1982).

In an attempt to extend storage life of avocado fruit, we stored them at $2 \mathrm{C}$ and examined the effect of low- $\mathrm{O}_{2}$ atmosphere pretreatments on maintaining their quality and preventing CI development at this otherwise injurious temperature.

\section{Materials and Methods}

Mature 'Fuerte' avocado fruit were harvested from the central plain of Israel and treated on the day of harvest. The fruit were enclosed in three 30-liter plastic containers
(30 fruit in each one) and exposed to nearanaerobic conditions for $24 \mathrm{~h}$ at $17 \mathrm{C}$. Nitrogen from a $\mathrm{N}_{2}$ generator (Rittal, Enfield, U.K.) was flushed for $1 \mathrm{~h}$ at $400 \mathrm{ml} \cdot \mathrm{min}^{-1}$ via a water flask into the containers. After reaching 3\% $\mathrm{O}_{2}+$ $97 \% \mathrm{~N}_{2}$, the containers were sealed for $24 \mathrm{~h}$, then opened, and the fruit were transferred to fiberboard boxes. The control fruit had remained in the treatment room at $17 \mathrm{C}[90 \%$ relative humidity $(\mathrm{RH})]$. After treatment, all fruit were stored in air at $2 \mathrm{C}(90 \% \mathrm{RH})$ for 3 weeks and then transferred to $17 \mathrm{C}$.

At the end of the treatment, head space samples were taken from the jars, and the concentrations of AA, ethanol, $\mathrm{CO}_{2}, \mathrm{~N}_{2}$, and $\mathrm{O}_{2}$ were determined by gas chromatography using either a flame ionization detector (AA, ethanol) or a thermal conductivity detector $\left(\mathrm{CO}_{2}, \mathrm{O}_{2}, \mathrm{~N}_{2}\right)$ as described by Pesis and BenArie (1984).

CI severity based on external damage was scored on 60 fruit per treatment using a subjective scale: $0=$ no damage, $1=$ very light damage, 2 = light damage, $3=$ medium damage, $4=$ severe damage, $5=$ very severe damage. The CI index was calculated according to the following formula:

Injury index $=\sum_{0}^{5}$ (injury level $) \times($ number of
0
fruits at this level $) /$ total number of fruits

Chlorophyll concentration in the peel was also used as a damage index. Six peel disks, 12 $\mathrm{mm}$ in diameter (total weight $0.6 \mathrm{~g}$ ), were put in $10 \mathrm{ml}$ of boiling $85 \%$ ethanol. The flasks were shaken at $70 \mathrm{C}$ for $2 \mathrm{~h}$, and chlorophyll a and $b$ were measured at 665 and $649 \mathrm{~nm}$. The amount of chlorophyll was calculated according to Wintermans and De Mots (1965). The results were expressed as the ratio between the chlorophyll concentrations of low- $\mathrm{O}_{2}$-treated fruit and controls.

Carbon dioxide and ethylene production were determined using individual fruit held in 2-liter jars at $2 \mathrm{C}$ for 3 weeks before transfer to $17 \mathrm{C}$ for 8 days. Carbon dioxide and ethylene in the headspace were detected by gas chromatography as described previously (Lurie and Pesis, 1992; Pesis and Ben-Arie, 1984). Data are means of five measurements for each treatment at each temperature.

Samples of five fruit from each treatment were removed once a week during the $2 \mathrm{C}$ storage and every 2 days during 8 days at $17 \mathrm{C}$ for further examination. Fruit firmness was measured on two pared sides of each fruit (10 measurements per treatment) using an electronic penetrometer (Chatillon, New York) with a $6.5-\mathrm{mm}$ conical tip.

Six 12-mm-diameter disks were prepared from each avocado peel (total weight $0.6 \mathrm{~g}$ ) and incubated in $10 \mathrm{ml} 0.3 \mathrm{~m}$ mannitol (five samples per treatment). Electrolyte leakage was measured after $3 \mathrm{~h}$ of incubation in a shaking water bath at $25 \mathrm{C}$. The electrical conductivity was measured at room temperature with a microprocessor conductivity meter (WTW, Weilheim, Germany). The tissue and the mannitol solution then were frozen at $-20 \mathrm{C}$, thawed, and boiled for $10 \mathrm{~min}$. Total 
conductivity was then measured. Rates of electrolyte leakage are expressed as changes in the percentage of the total conductivity per hour (Lafuente et al., 1991).

Total SH content was determined by boiling disks ( $12 \mathrm{~mm}$ in diameter; $0.6 \mathrm{~g}$ ) of peel or pulp in $5 \mathrm{ml}$ of $0.02 \mathrm{M}$ phosphate buffer $(\mathrm{pH}$ 5.7; five samples per treatment) for $10 \mathrm{~min}$. After centrifugation at $10,000 \times g$, the watersoluble SH compounds were determined in the supernatant using 5,5-dithiobis (2nitrobenzoic acid) (DTNB) reagent. The DTNB-reactive compounds were determined spectrophotometrically at $412 \mathrm{~nm}$ according to the method of Ellman (1959).

All measurements were done on five fruit per treatment, except for the CI measurements, which were measured on 60 fruit per treatment after 3 weeks at $2 \mathrm{C}$. All data were subjected to analysis of variance. The experiments were done in two subsequent years several times. Results of two representative experiments are presented.

\section{Results and Discussion}

During the $24 \mathrm{~h}$ that the fruit were exposed to low $\mathrm{O}_{2}$, there was an accumulation of the anaerobic metabolites AA, ethanol, and $\mathrm{CO}_{2}$ (Table 1). The $\mathrm{CO}_{2}$ produced was mainly due to anaerobic respiration. The change in $\mathrm{O}_{2}$ concentration during the $24 \mathrm{~h}$ was only $1.7 \%$, while that of $\mathrm{CO}_{2}$ was $7.1 \%$, which resulted in a respiratory quotient of 4.2. The ethanol levels produced were $>30$ times higher than the AA level, probably because ethanol is an endproduct metabolite in anaerobic respiration while AA is an intermediate. In other fruit, such as persimmon (Diospyros kaki L.F.) peach, and tomato, the accumulation of ethanol under anaerobic conditions is also much higher than that of AA (Lurie and Pesis, 1992; Pesis and Ben-Arie, 1984; Pesis and Marinansky, 1993).

Pretreatment with low $\mathrm{O}_{2}$ for $24 \mathrm{~h}$ before storage at $2 \mathrm{C}$ reduced $\mathrm{CI}$ symptoms significantly (Fig. 1). After 3 weeks at 2C, some of the treated fruit exhibited only slight CI, while most of the control fruit showed severe CI on $>50 \%$ of the peel surface, resulting in a CI index 3 times higher than in the treated fruit

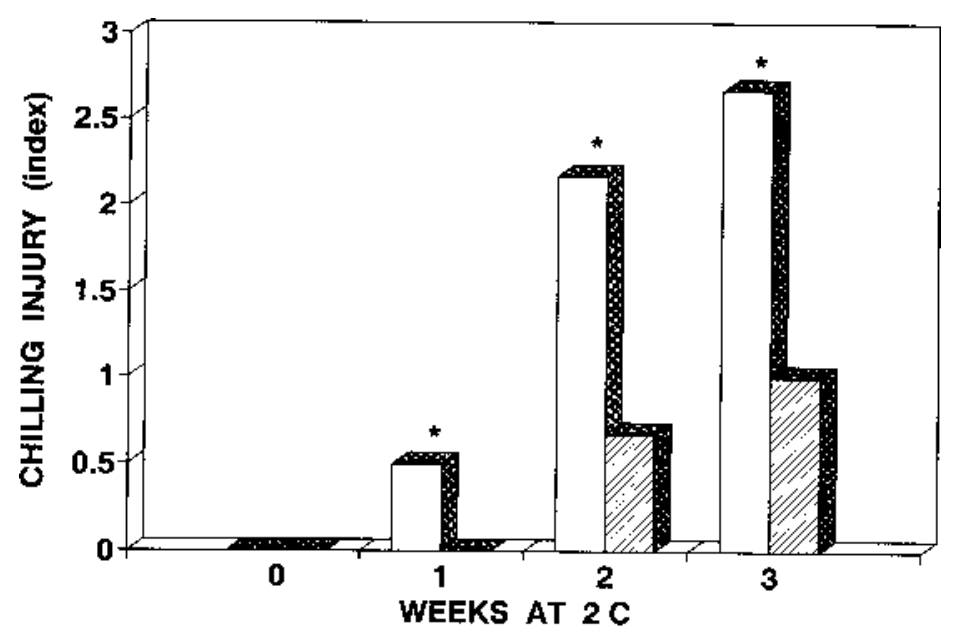

\section{CONTROL LOW OXYGEN}

Fig. 1. Effect of a 24-h low- $\mathrm{O}_{2}$ pretreatment at $17 \mathrm{C}$ on chilling injury $(\mathrm{CI})$ in avocado during 3 weeks at $2 \mathrm{C}$. $\mathrm{CI}$ index was calculated from 60 fruit. $\mathrm{CI}$ index: $0=$ none, $5=$ severe. *Significant differences between treatments, $P \leq 0.05$.

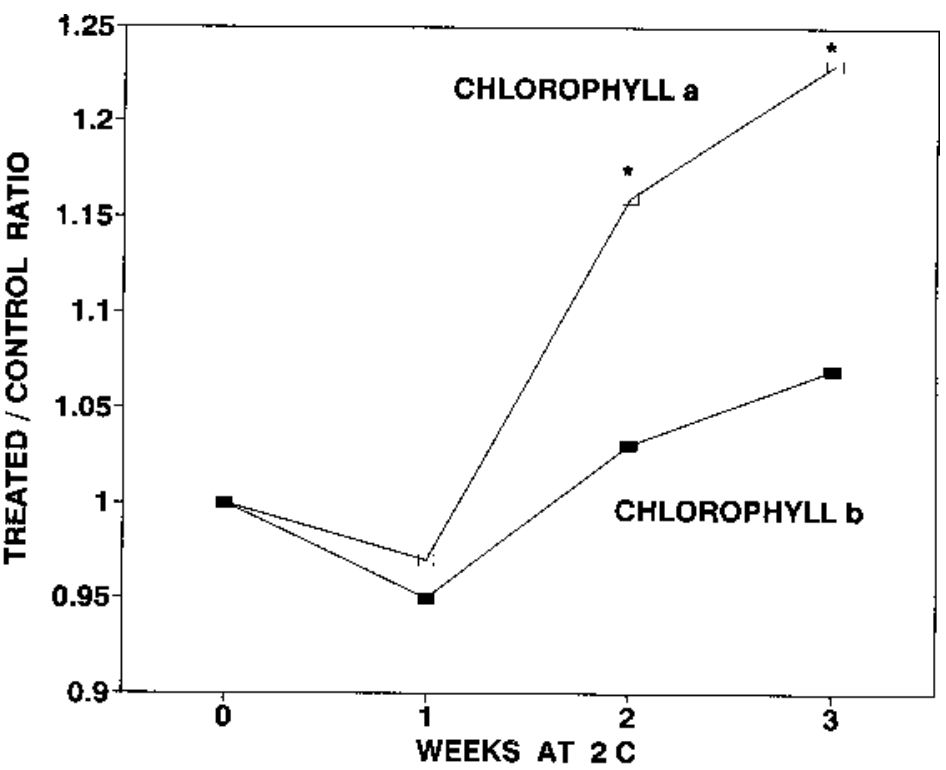

Fig. 2. Effect of a $24-\mathrm{h}$ low $-\mathrm{O}_{2}$ pretreatment at $17 \mathrm{C}$ on chlorophyll a and chlorophyll $\mathrm{b}$ as expressed by the ratio between low- $\mathrm{O}_{2}$-treated and control fruit of avocado during 3 weeks at $2 \mathrm{C}$. Results are the means of five measurements. *Difference significant from ratio $=1.0, P \leq 0.05$. (Fig. 1). During holding at $17 \mathrm{C}$, the control fruit showed more intense CI symptoms and they had started to decay, while the treated fruit maintained a better appearance with milder CI symptoms. CI in 'Fuerte' avocado is a common occurrence in storage at $2 \mathrm{C}$ (Zauberman et al., 1985). The reduction in CI attributable to low- $\mathrm{O}_{2}$ pretreatment is similar to the effects of pretreatment with high $\mathrm{CO}_{2}$ (Bertolini et al., 1991; Hatton et al., 1975; Marcellin and Chaves, 1983) and by temperature conditioning (Hariyadi and Parkin, 1991;

Lafuente et al., 1991; Lurie and Klein, 1991). Avocado peel is rich in chlorophyll, and the amount of chlorophyll extracted from the peel was found to be inversely correlated with the severity of the CI $(r=0.821)$. The higher the CI index, the less chlorophyll extracted, so that in low- $\mathrm{O}_{2}$-treated fruit more chlorophyll was extracted compared to the chilled control fruit (Fig. 2). The reduction in chlorophyll in damaged peel compared with nondamaged peel was mainly in chlorophyll a and not in chlorophyll b (Fig. 2). Measurement of chlo-

Table 1. Headspace concentration of various volatiles in containers containing 30 'Fuerte' fruit after $1 \mathrm{~h}$ and $24 \mathrm{~h}$ of sealing. Data are means of three jars \pm SE.

\begin{tabular}{lccccr}
\hline $\begin{array}{l}\text { Time } \\
(\mathrm{h})\end{array}$ & $\begin{array}{c}\mathrm{CO}_{2} \\
(\%)\end{array}$ & $\begin{array}{c}\mathrm{O}_{2} \\
(\%)\end{array}$ & $\begin{array}{c}\mathrm{N}_{2} \\
(\%)\end{array}$ & $\begin{array}{c}\text { Acetaldehyde } \\
(\mathrm{ppm})\end{array}$ & $\begin{array}{c}\text { Ethanol } \\
(\mathrm{ppm})\end{array}$ \\
\hline 1 & $1.4 \pm 0.08$ & $3.2 \pm 0.16$ & $95.8 \pm 0.69$ & 0.0 & $3.2 \pm 0.12$ \\
24 & $8.5 \pm 0.70$ & $1.5 \pm 0.23$ & $89.9 \pm 0.46$ & $1.8 \pm 0.43$ & $59.4 \pm 8.69$ \\
\hline
\end{tabular}

HortScience, Vol. 29(9), September 1994 rophyll as an index for $\mathrm{CI}$ is a different method from the one suggested by Chaplin et al.(1982), who measured CI as the absorbance of extracts from the discolored areas of CI-affected fruit.

Upon removal of the fruit from $2 \mathrm{C}$ storage, there was no difference in fruit firmness between treated and nontreated fruit (Fig. 3). However, during subsequent holding at $17 \mathrm{C}$, the low- $\mathrm{O}_{2}$-treated fruit remained slightly firmer than those not treated. In control and treated fruit, there was a dramatic decrease in firmness between 4 and 6 days, but the difference between treatments was significant only at 8 and 10 days. Only after 11 days at $17 \mathrm{C} \mathrm{did}$ the difference in firmness between treated and nontreated fruit disappear (Fig. 3).

Nontreated avocado fruit increased in ethylene production during the 19 days of storage at $2 \mathrm{C}$, while the low- $\mathrm{O}_{2}$-treated fruit had consistently low ethylene production (Fig. 4A). 


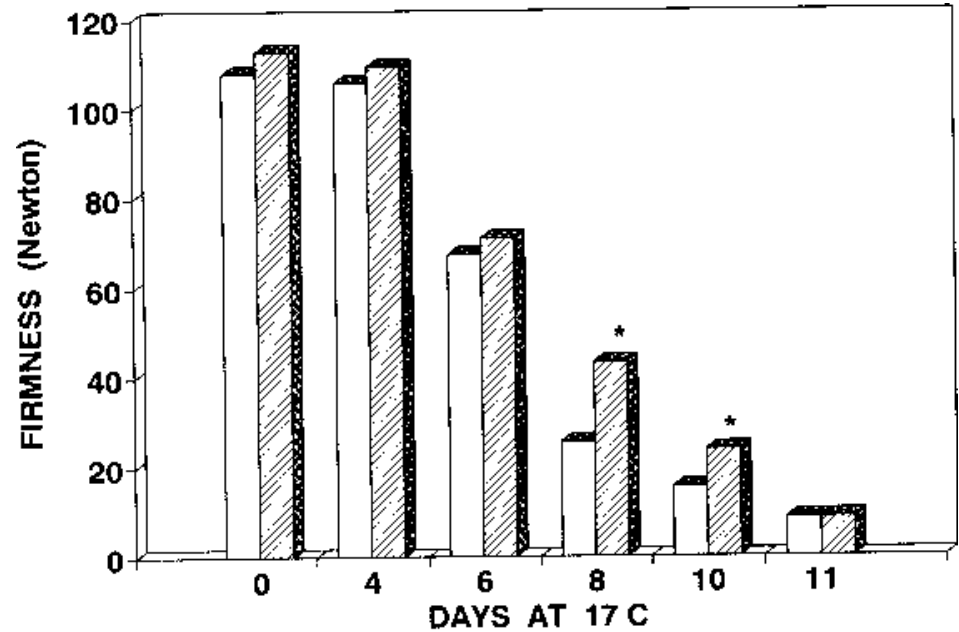

CONTROL LOW OXYGEN

Fig. 3. Effect of a $24-\mathrm{h}$ low- $\mathrm{O}_{2}$ pretreatment at $17 \mathrm{C}$ on firmness of avocado stored at $2 \mathrm{C}$ for 3 weeks and then held at $17 \mathrm{C}$ for periods indicated. Results are the means of 10 measurements (two measurements per fruit). *Significant differences between treatments, $P \leq 0.05$
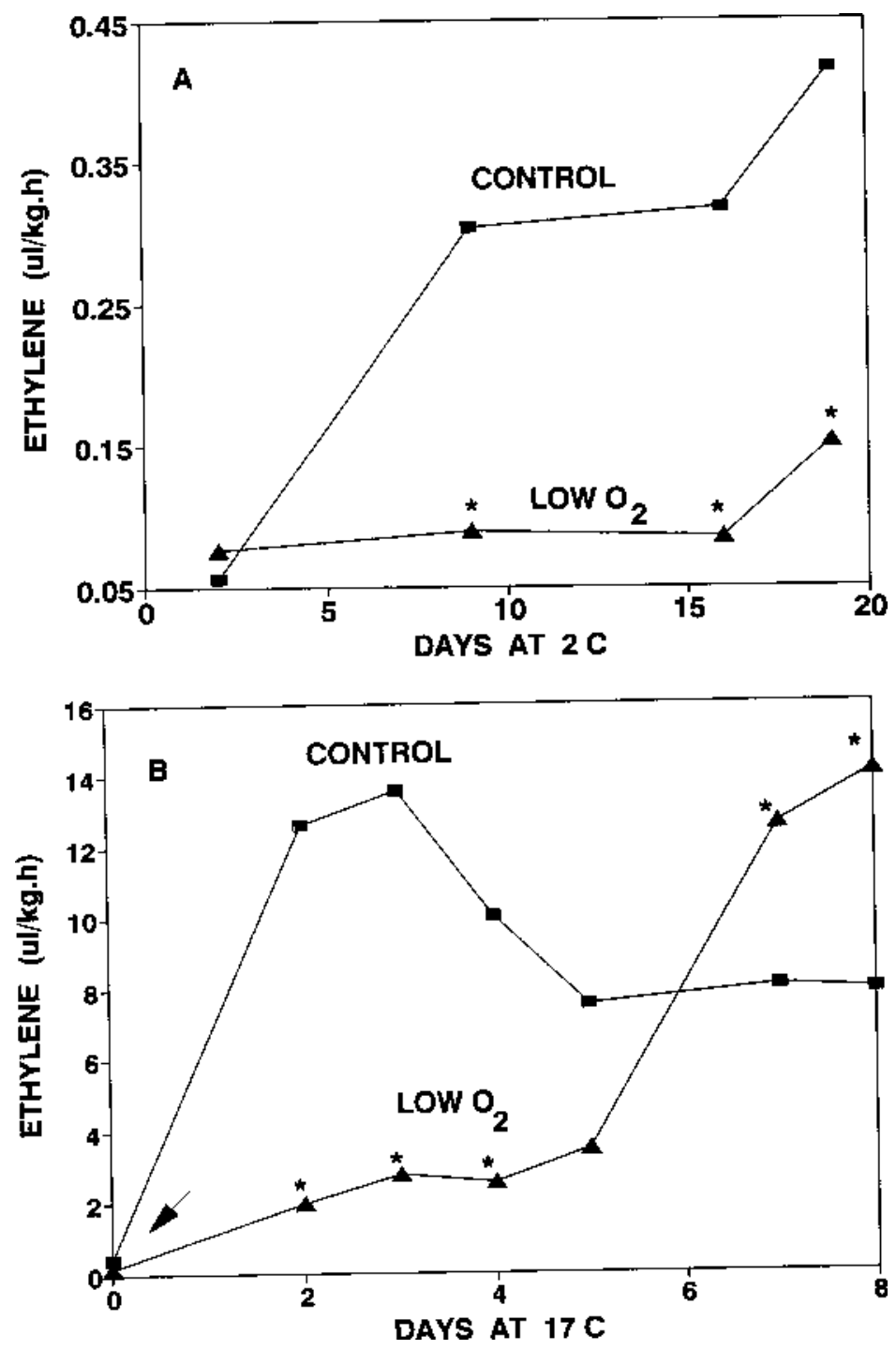

Fig. 4. Effect of a $24-\mathrm{h}$ low- $\mathrm{O}_{2}$ pretreatment at $17 \mathrm{C}$ on ethylene production in avocado during storage at (A) $2 \mathrm{C}$ followed by storage at (B) 17C. Results are the means of five measurements. Arrow in B indicates time of transfer from 2 to $17 \mathrm{C}$. * Significant differences between treatments, $P \leq 0.05$.
After removal of the control fruit to $17 \mathrm{C}$ for ripening, the climacteric peak of ethylene production occurred within 2 days, while in the low- $\mathrm{O}_{2}$-treated fruit, the climacteric increase was delayed 4 days (Fig. 4B). This result is similar to data presented by Marcelline and Chaves (1983), who showed a reduction in ethylene production at $4 \mathrm{C}$ in avocados pretreated with $20 \% \mathrm{CO}_{2}$. Anaerobic metabolites produced during exposure to low $\mathrm{O}_{2}$ and/or elevated $\mathrm{CO}_{2}$ concentrations may affect ethylene production. Saltveit and Mencarelli (1988) suggested that ethanol vapors inhibit 1aminocyclopropane-1-carboxylic acid (ACC) conversion to ethylene in tomato disks. In grape (Vitis vinifera L.) halves treated with ACC, ethylene production was inhibited by AA but not by ethanol (Pesis and Marinansky, 1992).

Carbon dioxide production was higher in nontreated fruit than in treated fruit during $2 \mathrm{C}$ storage (Fig. 5A). However, upon removal to $17 \mathrm{C}$, a dramatic increase in respiration occurred in both types of fruit, which might have been a result of the increase in temperature. Still, in the first days after removal, fruit formerly under low $\mathrm{O}_{2}$ had a lower respiration rate than the nontreated fruit (Fig. 5B). Grapefruit (Citrus paradisi Macfad.) with CI had higher rates of $\mathrm{CO}_{2}$ and ethylene evolution (McCollum and McDonald, 1991). Delay in the climacteric peak of $\mathrm{CO}_{2}$ and ethylene production after low- $\mathrm{O}_{2}$ pretreatment was shown also in banana and peach stored at 20C (Lurie and Pesis, 1992; Wills et al., 1982).

During 24 days of storage at $2 \mathrm{C}$, there was a gradual increase in electrolyte leakage in the peel of treated and nontreated fruit, although the rate of increase mostly was lower in fruit treated with low $\mathrm{O}_{2}$ (Fig. 6). During ripening at $17 \mathrm{C}$, there was a further substantial increase in electrolyte leakage, but differences between treated and nontreated fruit, although nonsignificant at $P \leq 0.05$, remained (Fig. 6). Ion leakage is considered a qualitative indicator of CI (McCollum and McDonald, 1991). Temperature conditioning for a short period before cold storage significantly reduced the electrolyte leakage and CI in cucumber cotyledons and tomato fruit (Lafuente et al., 1991; Lurie and Klein, 1991). However, Fuchs et al. (1989) stated that in 'Hass' avocado and 'Haden' mango (Mangifera indica L.), electrolyte leakage from fruit pulp is related to ripening and cannot serve as an indication for the development or presence of CI symptoms in the fruit. The lower leakage reported here was found to be significant only after 2 and 3 weeks at 2C and can be related to the $\mathrm{CI}$ because there were only minor differences in firmness at this stage between the treated and nontreated fruit.

The fruit pretreated with low $\mathrm{O}_{2}$ had higher concentrations of total free $\mathrm{SH}$ groups in pulp (Fig. 7A) and peel (Fig. 7B) than the control. The difference in the pulp was significant at 17 and 24 days of storage at $2 \mathrm{C}$, while in the peel, it was significant from day 9 to 24 at $2 \mathrm{C}$ and also later, after removal to $17 \mathrm{C}$ (day 27 and 32). In the pulp, the levels of SH groups were 3 times higher than those in the peel. However, the relative difference in the $\mathrm{SH}$ concentration 

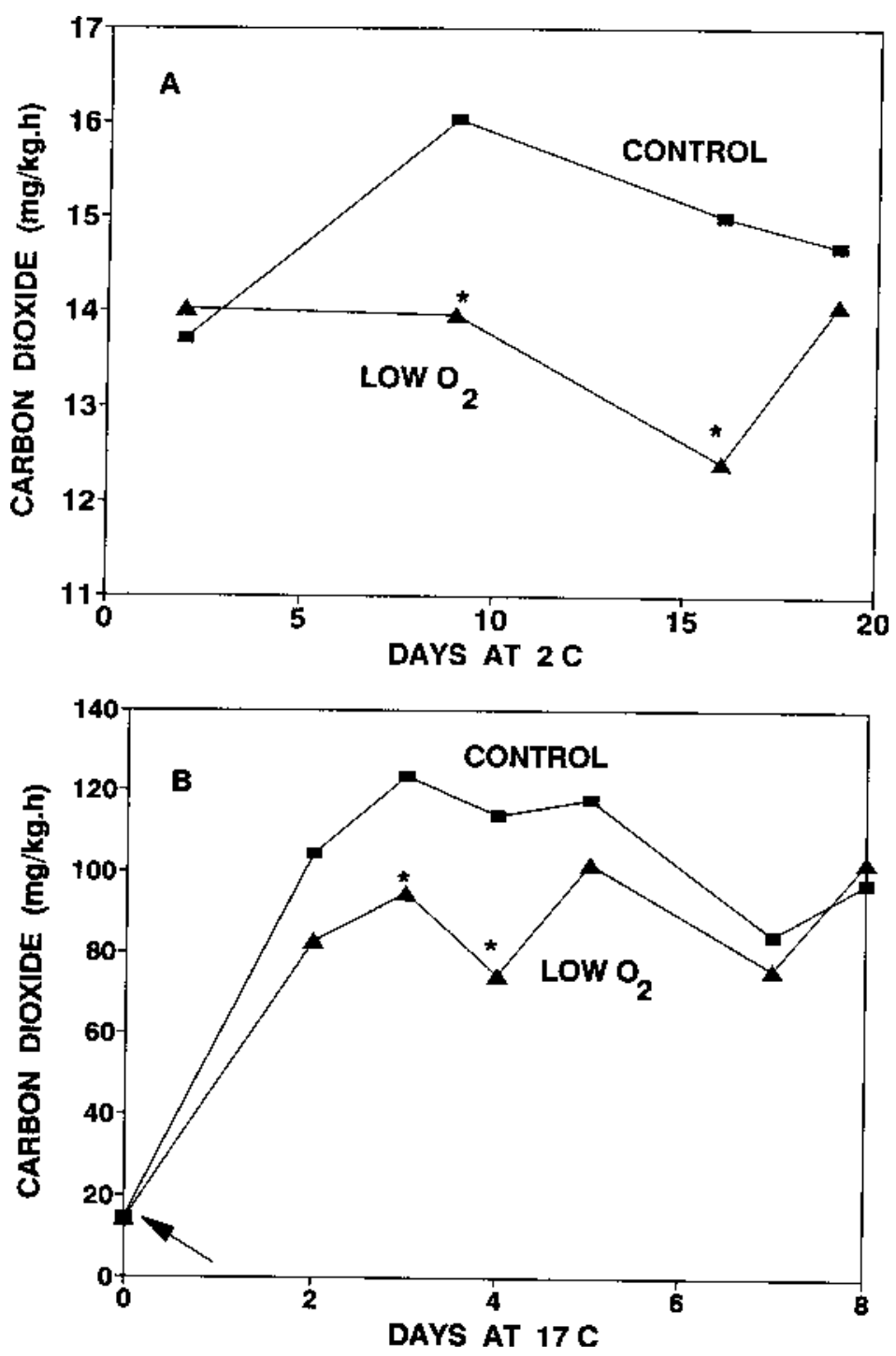

Fig. 5. Effect of a 24-h low- $\mathrm{O}_{2}$ pretreatment at $17 \mathrm{C}$ on $\mathrm{CO}_{2}$ production in avocado during storage at (A) $2 \mathrm{C}$ followed by storage at (B) 17C . Results are the means of five measurements. Arrow in B indicates time of transfer from 2 to $17 \mathrm{C}$. *Significant differences between treatments, $P \leq 0.05$.

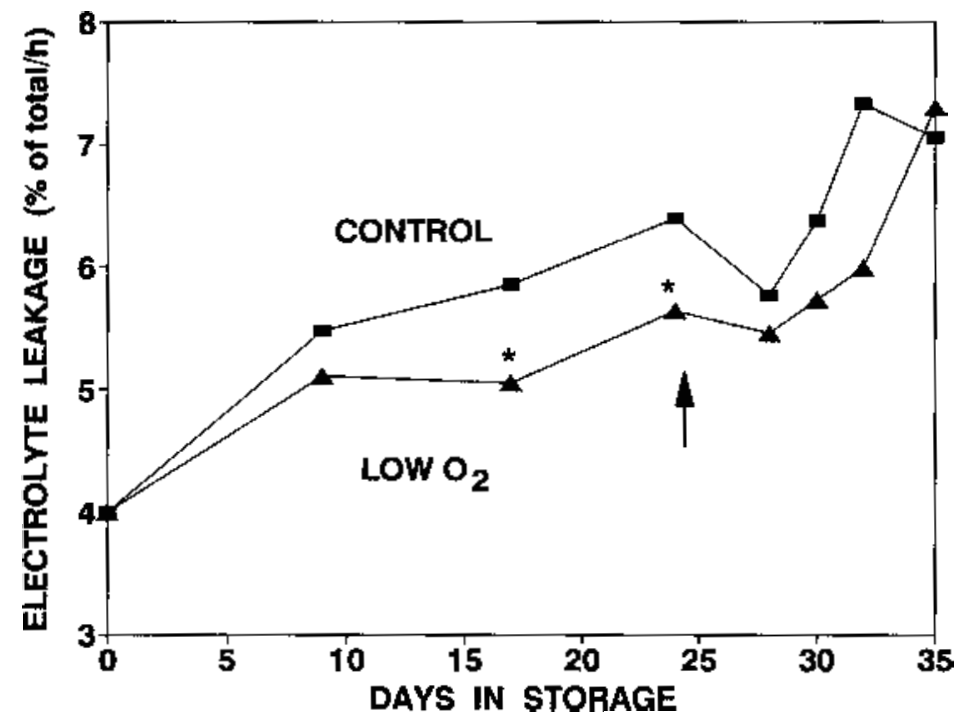

Fig. 6. Effect of a 24-h low- $\mathrm{O}_{2}$ pretreatment at $17 \mathrm{C}$ on ion leakage in the peel of avocado during storage at $2 \mathrm{C}$ followed by storage at $17 \mathrm{C}$. Results are the means of five measurements. Arrow indicates time of transfer from 2 to $17 \mathrm{C}$. $*$ Significant differences between treatments, $P \leq 0.05$. between the low- $\mathrm{O}_{2}$-treated fruit and the nontreated fruit was much greater in the peel (Fig. 7B) than that in the pulp (Fig. 7A). In avocado, the symptoms of CI begin in the peel (Zauberman et al., 1985). During ripening of climacteric fruit, such as tomato and mango, there is a gradual increase in free $\mathrm{SH}$ groups (mainly cysteine and glutathione) that may serve as natural detoxification agents (Fuchs et al., 1981; Tabachnik-Ma'ayan and Fuchs, 1982). Levitt et al. (1962) suggested that an increase in SHs enhanced cold hardiness. Glutathione also helps protect plant tissues from peroxides that are generated during oxidative stress (Foster and Hess, 1980). Lower levels of reduced glutathione were found in chilled than in nonchilled fruit (Hariyadi and Parkin, 1991).

Higher levels of reducing ( $\mathrm{SH}$ ) groups in low- $\mathrm{O}_{2}$-pretreated fruit might indicate a more active antioxidant defense mechanism, which in turn can explain the milder CI symptoms. The external application of antioxidants reduced the severity of CI in chilled cucumber and bell pepper (Capsicum annuum L.) fruit (Wang and Baker, 1979). Low-O $\mathrm{O}_{2}$ pretreatment of avocado possibly results in a higher level of reducing power $(\mathrm{SH})$ and greater membrane integrity, which together increase the fruit resistance to CI.

The induction of AA and ethanol formation (Table 1) during low- $\mathrm{O}_{2}$ treatment may play a role in inhibiting ripening and reducing CI. AA is an active molecule in plant tissues because it can form covalent bonds with protein-containing $\mathrm{NH}_{2}$ groups by forming a Schiff base (Perata, 1992). Frenkel and Erez (1992) suggested that ethanol vapors reduce CI symptoms in cucumber seedlings as a result of biophysical changes. In addition, anaerobic treatment of plant tissues induced the synthesis of anaerobic stress proteins and the disruption of normal protein synthesis (Nover, 1989).

We have shown that a 24-h treatment with $3 \% \mathrm{O}_{2}+97 \% \mathrm{~N}_{2}$ resulted in increased production of AA, ethanol, and free $\mathrm{SH}$ groups, which led to delayed softening, inhibition of ethylene production, and reduced CI damage of 'Fuerte' avocado during storage at $2 \mathrm{C}$ and upon return to ambient conditions. The mechanisms directly responsible for these phenomena bear further study.

\section{Literature Cited}

Bertolini, P., G. Lanza, and G. Tonini. 1991. Effect of pre-storage carbon dioxide treatments and storage temperatures on membranosis of 'Femminello comune' lemons. Sci. Hort. 46:89-95.

Bower, J.P., J.G.M. Cutting, and A.B. Truter. 1989 Modified atmosphere storage and transport of avocados-What does it mean. South African Avocado Growers' Assn. Yrbk. 12:17-20.

Chaplin, G.R., R.B.H. Wills, and D. Graham. 1982 Objective measurement of chilling injury in the mesocarp of stored avocados. HortScience $17: 238-239$

Ellman, G.L. 1959. Tissue sulfhydryl groups. Arch Biochem. Biophys. 82:70-77.

Foster, J.G. and J.L. Hess. 1980. Response of superoxide dismutase and glutathione reductase activities in cotton leaf tissue exposed to an atmosphere enriched in oxygen. Plant Physiol. 66:482-487. 

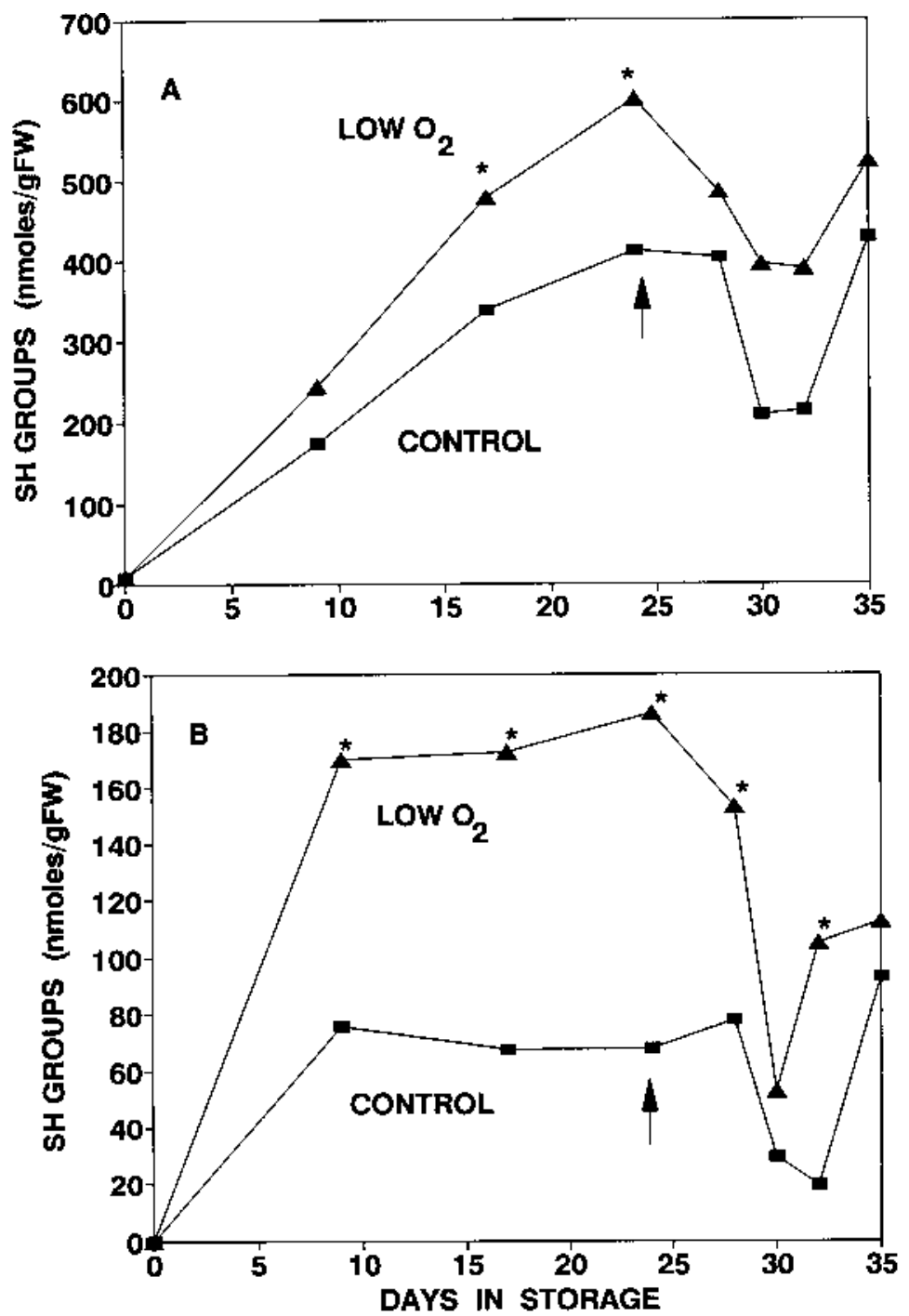

Fig. 7. Effect of a $24-\mathrm{h}$ low- $\mathrm{O}_{2}$ pretreatment at $17 \mathrm{C}$ on the concentration of $\mathrm{SH}$ groups content in the (A) pulp or (B) peel of avocado during storage at $2 \mathrm{C}$ followed by storage at $17 \mathrm{C}$. Results are the means of five measurements. Arrows indicate time of transfer from 2 to $17 \mathrm{C}$. *Significant differences between treatments, $P \leq 0.05$. Note that ordinate scales for parts A and B differ by a factor of $\approx 3.5$.

Frenkel, C. and A. Erez. 1992. Arrest of chillingstress in cucumber seedling by endogenous and applied ethanol. Plant Physiol. 99(1):10. (Abstr. 59)

Fuchs, Y.,E. Pesis, G.Zauberman, and L. Tabachnik. 1981. Free sulfhydryl groups in ripening tomato fruits. Plant \& Cell Physiol. 22:733-736.

Fuchs, Y., G. Zauberman, I. Rot, and A. Wexsler. 1989. Chilling injury and electrolyte leakage in cold stored mango and avocado fruits. Acta Hort. 258:303-308.

Hariyadi, P. and K.L. Parkin. 1991. Chilling-induced oxidative stress in cucumber fruits. Postharvest Biol. \& Technol. 1:33-45.

Hatton, T.T., R.H. Cubbedge, and W. Grierson. 1975. Effects of prestorage carbon dioxide treatments and delayed storage on chilling injury of
'Marsh' grapefruit. Proc. Fla. State Hort. Soc. 88:335-338

Kelly, M.O. and M.E. Saltveit. 1988. Effect of endogenously synthesized and exogenously applied ethanol on tomato fruit ripening. Plant Physiol. 88:143-147.

Lafuente, M.T., A. Belver, M.G. Guye, and M.E. Saltveit. 1991. Effect of temperature conditioning on chilling injury of cucumber cotyledons. Plant Physiol. 95:443-449.

Levitt, J., C.Y. Sullivan, and N.O. Johansson. 1962. Sulfhydryls-A factor in frost resistance III. Relation of SH increase during hardening to protein, glutathione and glutathione oxidizing activity. Plant Physiol. 37:266-276.

Lurie, S. and J.D. Klein. 1991. Acquisition of lowtemperature tolerance in tomatoes by exposure to high-temperature stress. J. Amer. Soc. Hort. Sci. 116:1007-1012.

Lurie, S. and E. Pesis. 1992. Effect of acetadehyde and anaerobiosis as postharvest treatments on the quality of peaches and nectarines. Postharvest Biol. \& Technol. 1:317-326.

Lyons, J.M. 1973. Chilling injury in plants. Annu. Rev. Plant Physiol. 24:445-466.

Marcellin, P. and A. Chaves. 1983. Effect of intermittent high $\mathrm{CO}_{2}$ treatment on storage life of avocado fruit in relation to respiration and ethylene production. Acta Hort. 138:155-163.

McCollum, T.G. and R.E. McDonald. 1991. Electrolyte leakage, respiration, and ethylene production as indices of chilling injury in grapefruit. HortScience 26:1191-1192.

Nover, L. 1989. Anaerobic stress, p. 89-90. In: L. Nover, D. Neumann, and K.D. Scharf (eds.). Heat shock and other stress response systems of plants. Springer-Verlag, Berlin.

Perata, P., P. Vernieri, D. Armellini, M. Bugnoli, F. Tognoni, and A. Alpi. 1992. Immunological detection of acetaldehyde-protein adducts in ethanol-treated carrot cells. Plant Physiol. 98:913-918.

Pesis, E. and R. Ben-Arie. 1984. Involvement of acetaldehyde and ethanol accumulation during induced deastringency of persimmon fruits. J. Food Sci. 49:896-899.

Pesis, E. and R. Marinansky. 1992. Carbon dioxide and ethylene production in response to acetaldehyde and ethanol treatments in grapes. J. Amer. Soc. Hort. Sci. 117:110-113.

Pesis, E. and R. Marinansky. 1993. Inhibition of tomato ripening by acetaldehyde vapour or anaerobic conditions prior to storage. J. Plant Physiol. 142:717-721.

Saltveit, M.E. and F. Mencarelli. 1988. Inhibition of ethylene synthesis and action in ripening tomato fruit by ethanol vapors. J. Amer. Soc. Hort. Sci. 113:572-576.

Scott, K.J. and G.R. Chaplin. 1978. Reduction of chilling injury in avocados stored in sealed polyethylene bags. Trop. Agr. (Trinidad) 55:87-90.

Tabachnik-Ma'ayan, L. and Y. Fuchs. 1982. Free sulfhydryl groups in ripening fruits. Plant \& Cell Physiol. 23:1309-1314.

Wang, C.Y. and J.E. Baker. 1979. Effects of two free radical scavengers and intermittent warming on chilling injury and polar lipid composition of cucumber and sweet pepper fruits. Plant \& Cell Physiol. 20:243-251.

Wills, R.B.H., A. Klieber, R. David, and M. Siridhata. 1990. Effect of brief premarketing holding of bananas in nitrogen on time to ripen. Austral. J. Expt. Agr. 30:579-581.

Wills, R.B.H., S. Pitakserikul, and K.J. Scott. 1982. Effects of prestorage in low oxygen or high carbon dioxide concentrations on delaying the ripening of bananas. Austral. J. Agr. Res. 23:1029-1036

Wintermans, J.F.G. and A. De Mots. 1965. Spectrophotometric characteristics of chlorophylls a and $b$ and their pheophytins in ethanol. Bioch. Biophys. Acta 109:448-454.

Zauberman, G., Y. Fuchs, and M. Akerman. 1985. Peroxidase activity in avocado fruit stored at chilling temperatures. Sci. Hort. 26:261-265. 